\title{
Glucagon-Like Peptide 1 Excites Hypocretin/Orexin Neurons by Direct and Indirect Mechanisms: Implications for Viscera-Mediated Arousal
}

\author{
Claudio Acuna-Goycolea and Anthony van den Pol \\ Department of Neurosurgery, Yale University School of Medicine, New Haven, Connecticut 06520
}

\begin{abstract}
Glucagon-like peptide 1 (GLP-1) is produced by neurons in the caudal brainstem that receive sensory information from the gut and project to several hypothalamic regions involved in arousal, interoceptive stress, and energy homeostasis. GLP-1 axons and receptors have been detected in the lateral hypothalamus, where hypocretin neurons are found. The electrophysiological actions of GLP-1 in the CNS have not been studied. Here, we explored the GLP-1 effects on GFP (green fluorescent protein)-expressing hypocretin neurons in mouse hypothalamic slices. GLP-1 receptor agonists depolarized hypocretin neurons and increased their spike frequency; the antagonist exendin (9-39) blocked this depolarization. Direct GLP-1 agonist actions on membrane potential were abolished by choline substitution for extracellular $\mathrm{Na}^{+}$, and dependent on intracellular GDP, suggesting that they were mediated by sodium-dependent conductances in a G-protein-dependent manner. In voltage clamp, the GLP-1 agonist Exn4 (exendin-4) induced an inward current that reversed near - 28 $\mathrm{mV}$ and persisted in nominally $\mathrm{Ca}^{2+}$-free extracellular solution, consistent with a nonselective cationic conductance. GLP-1 decreased afterhyperpolarization currents. GLP-1 agonists enhanced the frequency of miniature and spontaneous EPSCs with no effect on their amplitude, suggesting presynaptic modulation of glutamate axons innervating hypocretin neurons. Paraventricular hypothalamic neurons were also directly excited by GLP-1 agonists. In contrast, GLP-1 agonists had no detectable effect on neurons that synthesize melanin-concentrating hormone (MCH). Together, our results show that GLP-1 agonists modulate the activity of hypocretin, but not $\mathrm{MCH}$, neurons in the lateral hypothalamus, suggesting a role for GLP-1 in the excitation of the hypothalamic arousal system possibly initiated by activation by viscera sensory input.
\end{abstract}

Key words: feeding; neuropeptide; lateral hypothalamus; gut; NTS; interoceptive; narcolepsy

\section{Introduction}

Glucagon-like peptide 1 (GLP-1) is synthesized in the brain (Han et al., 1986; Jin et al., 1988; Larsen et al., 1997a), in which it may act as a neuromodulator (Kreymann et al., 1989). GLP-1 has been detected in the caudal brainstem in a subset of neurons in the nucleus of the solitary tract (NTS), a key relay of interoceptive information from the gut (Larsen et al., 1997a; Merchenthaler et al., 1999; Saper, 2002). GLP-1-containing axons ramify widely throughout the hypothalamus, particularly in the paraventricular nucleus (PVN), arcuate, and lateral hypothalamic (LH) regions (Han et al., 1986; Jin et al., 1988; Rinaman, 1999). In parallel, high levels of GLP-1 receptor mRNA have been found in the hypothalamus (Merchenthaler et al., 1999). GLP-1 receptors belong to the G-protein-coupled receptor family (Thorens, 1992) and have been postulated to act by increasing intracellular cAMP levels via the stimulatory G-protein $\mathrm{G}_{\mathrm{s}}$ (Drucker et al., 1987); the GLP-1

Received April 27, 2004; revised June 22, 2004; accepted July 26, 2004.

This work was supported by National Institutes of Health Grants NS34887, NS37788, and NS41454. C.A.-G. was supported in part by Chilean Conicyt (Beca de Apoyo de Tesis Doctoral). We thank Drs. T. L. Powley and G. Wollmann for helpful suggestions and V. Rougulin for technical assistance.

Correspondence should be addressed to Dr. Anthony N. van den Pol, Department of Neurosurgery, Yale University School of Medicine, 333 Cedar Street, New Haven, CT 06520. E-mail: anthony.vandenpol@yale.edu.

DOI:10.1523/JNEUROSCI.1607-04.2004

Copyright $\odot 2004$ Society for Neuroscience $\quad$ 0270-6474/04/248141-12\$15.00/0 receptor has also been reported to couple with the inhibitory $\mathrm{G}_{\mathrm{i} / \mathrm{o}}$ G-protein (Hallbrink et al., 2001).

The NTS, the primary source of GLP-1-containing neurons in the CNS, receives sensory information from the gut via the vagus nerve, and neurons here respond to a variety of gut sensory signals that relay information from gut stretch receptors and from gut fat and glucose sensors (Powley, 2000; Saper et al., 2002). GLP-1 neurons projecting to the hypothalamus may modulate blood pressure and heart rate (Yamamoto et al., 2002, 2003) and may initiate anxiety responses associated with interoceptive stress (Rinaman, 1999; Seeley et al., 2000; Kinzing et al., 2003). GLP-1 has also been postulated to reduce food intake (TangChristensen et al., 1996; Turton et al., 1996). CNS administration of GLP-1 inhibits food intake and increases Fos expression in the hypothalamus (Tang-Christensen et al., 1996; Turton et al., 1996; Larsen et al., 1997b). Repeated intracranial injections of GLP-1 or the GLP-1 receptor agonist exendin-4 (Exn4) cause a reduction in body weight (Meeran et al., 1999).

Hypocretin and melanin-concentrating hormone $(\mathrm{MCH})$ are expressed by different cell populations in the LH (Broberger et al., 1998; Elias et al., 1998; Peyron et al., 1998). Hypocretin enhances arousal (Hagan et al., 1999), potentially related to metabolic state (Yamanaka et al., 2003), and loss of hypocretin peptide or its receptors results in narcolepsy (Chemelli et al., 1999; Lin et al., 
1999; Nishino et al., 2000; Peyron et al., 2000; Thannickal et al., 2000). MCH neurons may also be involved in the regulation of energy homeostasis. MCH injections into the brain cause a robust increase in food intake (Qu et al., 1996; Rossi et al., 1999); blockade of the MCH receptor reduces body weight (Borowsky et al., 2002).

Although functional studies have shown many interesting effects of GLP-1 on behavior, we are unaware of any work on the cellular actions of GLP-1 in the CNS. Here, we studied the action of GLP-1 on the activity of hypocretin identified by green fluorescent protein (GFP) expression in hypothalamic slices. GLP-1 agonists consistently excited hypocretin neurons by direct postsynaptic, sodium-dependent mechanisms. GLP-1 enhanced release of glutamate from axons innervating hypocretin cells by a presynaptic mechanism. In contrast, GLP-1 agonists had no detectable effect on $\mathrm{MCH}$ neurons. These results suggest that GLP-1 acts selectively on the components of the LH that activate the hypothalamic arousal system.

\section{Materials and Methods}

Animals. To identify hypocretin cells, hypothalamic slices were prepared from transgenic mice [from Dr. T. Sakurai (University of Tsukuba, Tsukuba, Japan)] that selectively express GFP in hypocretin neurons ( $\mathrm{Li}$ et al., 2002; Yamanaka et al., 2003). MCH-containing neurons were identified by selective GFP expression after recombinant adeno-associated virus (AAV-MCH) infection in vivo or by using transgenic mice that selectively express GFP in MCH cells (van den Pol et al., 2004); the electrophysiological properties of $\mathrm{MCH}$ neurons were similar with each method of identification. We used 2- to 3-week-old animals maintained in a normal $12 \mathrm{hr}$ light/dark cycle. The Yale University Committee on Animal Care and Use approved all of the procedures used in this study.

Slice preparation. All of the slice preparation procedures were performed as previously described (Li et al., 2002; Acuna-Goycolea et al., 2004). Briefly, animals were deeply anesthetized (sodium pentobarbital, $100 \mathrm{mg} / \mathrm{kg}$ ), and then the brain was rapidly removed and placed in icecold oxygenated $\left(95 \% \mathrm{O}_{2}-5 \% \mathrm{CO}_{2}\right)$ solution that contained (in mM): 220 sucrose, $2.5 \mathrm{KCl}, 6 \mathrm{MgCl}_{2}, 1 \mathrm{CaCl}_{2}, 1.25 \mathrm{NaH}_{2} \mathrm{PO}_{4}, 26 \mathrm{NaHCO}_{3}$, and 10 glucose, $\mathrm{pH} 7.4$, with $\mathrm{HCl}$. A block of tissue containing the hypothalamus was dissected, and coronal slices $(200-300 \mu \mathrm{m})$ were cut in cold sucroseartificial CSF (ACSF) with a vibratome. The hypothalamic slices were equilibrated with $95 \% \mathrm{O}_{2}$ and $5 \% \mathrm{CO}_{2}$ and incubated for $1-2 \mathrm{hr}$ in an equilibrium chamber with standard ACSF containing (in mM): $124 \mathrm{NaCl}$, $3 \mathrm{KCl}, 2 \mathrm{MgCl}_{2}, 2 \mathrm{CaCl}_{2}, 1.23 \mathrm{NaH}_{2} \mathrm{PO}_{4}, 26 \mathrm{NaHCO}_{3}$, and 10 glucose, $\mathrm{pH}$ 7.4 , with $\mathrm{HCl}$. Then, a slice containing the $\mathrm{LH}$ was moved to a recording chamber mounted on an Olympus Optical (Tokyo, Japan) BX51WI upright microscope equipped with video-enhanced infrared-differential interference contrast (DIC) and fluorescence. Tissue was continuously superfused with a standard ACSF solution. The ACSF temperature in the chamber was maintained at $34-36^{\circ} \mathrm{C}$ using a dual-channel heater controller (Warner Instruments, Hamden, CT). Neurons were visualized with an Olympus Optical $40 \times$ water-immersion lens.

Electrophysiology. Low-resistance patch pipettes (4-6 M $\Omega$ ) made from borosilicate glass tubing (World Precision Instruments, Sarasota, FL) using a PP-83 vertical puller (Narishige, Tokyo, Japan) were used for whole-cell current- and voltage-clamp recordings. Recording pipettes were filled with a pipette solution that contained (in mM): $145 \mathrm{KMeSO}_{4}$ (or $\mathrm{KCl}$ for IPSCs), $1 \mathrm{MgCl}_{2}$, 10 HEPES, 1.1 EGTA, $2 \mathrm{Mg}$-ATP, and 0.5 $\mathrm{Na}_{2}$-GTP, $\mathrm{pH} 7.3$, with KOH. In the experiments in which calcium currents were studied, a $\mathrm{CsCH}_{3} \mathrm{SO}_{3}$-based pipette solution was used. This solution contained (in mM): $130 \mathrm{CsCH}_{3} \mathrm{SO}_{3}, 1 \mathrm{MgCl}_{2}, 10 \mathrm{HEPES}, 11$ EGTA-Cs, $2 \mathrm{Mg}$-ATP, and $0.5 \mathrm{Na}_{2}$-GTP, pH 7.3, with $\mathrm{CsOH}$. The bath solution used in these experiments contained (in $\mathrm{mM}$ ): $78.5 \mathrm{NaCl}, 40$ TEA-Cl, $3 \mathrm{KCl}, 2 \mathrm{MgCl}_{2}, 5 \mathrm{BaCl}_{2}, 1.25 \mathrm{NaH}_{2} \mathrm{PO}_{4}, 26 \mathrm{NaHCO}_{3}$, and 10
B

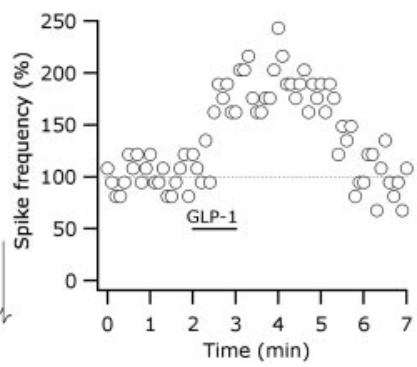

C

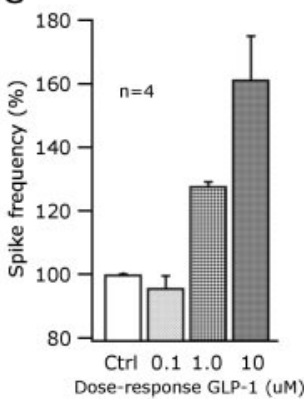

glucose, $\mathrm{pH}$ 7.4, with $\mathrm{HCl}$. The hypocretin or $\mathrm{MCH}$-expressing neurons were identified by the GFP fluorescence, and then DIC was used to achieve the cell-attached configuration in these cells. The whole-cell configuration was obtained after gentle application of negative pressure. Slow and fast compensation of the capacitance were automatically performed using Pulse software (HEKA Elektronik, Lambrecht/Pfalz, Germany). Access resistance was continuously monitored during the experiments. Only those cells in which access resistance (changes $<10 \%$ ) was stable were included in the analysis. An EPC9 amplifier and Pulse software were used for data acquisition (HEKA Elektronik). PulseFit (HEKA Elektronik), Axograph (Axon Instruments, Foster City, CA), and Igor Pro (WaveMetrics, Lake Oswego, OR) software were used for analysis.

Event detection and statistical analysis. Excitatory and inhibitory synaptic currents as well as miniature activity were detected using Axograph software (Clements and Bekkers, 1997). The detection was performed comparing the spontaneous events with a simulated template, which was generated based on an exponential function as described previously (Gao and van den Pol, 2001). Briefly, a template was generated based on a double-exponential function in which the time course (rise and decay) as well as the width of a typical synaptic current was used. Then, the template function was moved along the recorded trace, and every single event was compared with the template. To distinguish the synaptic events from background noise, only those events with amplitude $>5 \mathrm{pA}$ were included in the analysis.

Statistical analyses were performed using one-way ANOVA test for between-group (i.e., control, treatment, recovery) comparisons. To detect pairwise differences, ANOVA followed by a Bonferroni post hoc test for multiple comparisons was used. The nonparametric KolmogorovSmirnov test was used for comparison of the cumulative fractions of the amplitude before and after drug applications. A value of $p<0.05$ was considered statistically significant; data are reported as means \pm SEM throughout.

Reagents. Some of the reagents used were purchased from Sigma (St. Louis, MO) and include the following: DL-2-amino-5-phosphonovaleric acid (AP-5), 6-cyano-7-nitroquinoxaline-2,3-dione (CNQX), and bicuculline methiodide (BIC). Glucagon-like peptide 1 (7-36) amide was obtained from Bachem Bioscience (King of Prussia, PA), Exn4 from American Peptide Company (Sunnyvale, CA), exendin (9-39) amide $\left(\mathrm{Exn}_{9-39}\right)$ from Phoenix Pharmaceuticals (Belmont, CA), and tetrodotoxin (TTX) from Alomone Labs (Jerusalem, Israel).

\section{Results}

\section{Glucagon-like peptide 1 excites hypocretin neurons}

Using whole-cell current clamp, we evaluated the effect of GLP-1 on the spike frequency of hypocretin neurons in hypothalamic slices in vitro. Application of $1 \mu \mathrm{M}$ GLP-1 significantly increased the frequency of action potentials, returning to control levels 4-10 min after peptide washout (Fig. $1 A, B$ ). Representative traces showing the GLP-1 effect on the firing rate of hypocretin neurons are presented in Figure $1 A$. The time course of the GLP-1 effect is shown in Figure $1 B$. The excitatory effect was 
A

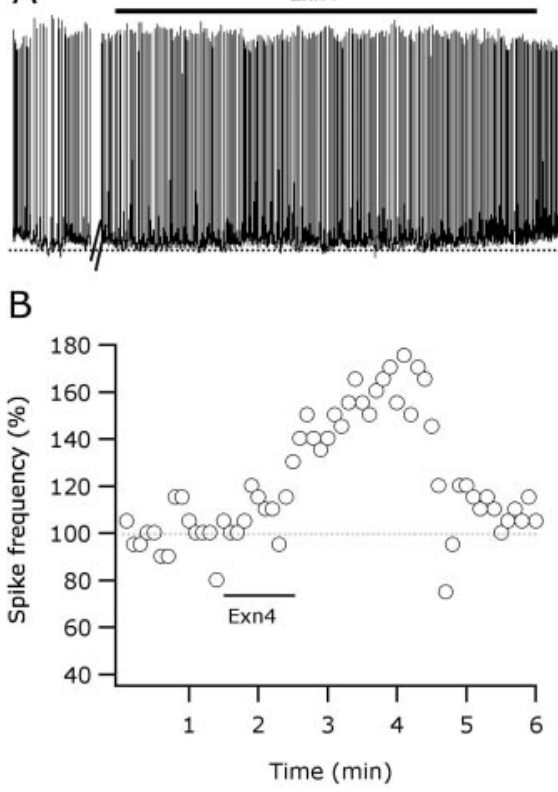

cretin neurons are attributable to the activation of voltage-dependent sodium channels ( $n=6$; data not shown). In the presence of TTX, Exn4 was delivered to the hypocretin cells for 1-2 min. Under these conditions, Exn4 resulted in a robust and long-lasting depolarization of the membrane potential in hypocretin cells (Fig. $3 A$, trace 1). The membrane potential was depolarized by $7.8 \pm 2.5 \mathrm{mV}$ in the presence of Exn 4 and returned to pretreatment levels after 3-10 min of Exn4 washout (Fig. 3B). These effects were statistically significant (ANOVA; $n=6 ; p<$ $0.05)$. In voltage clamp, holding the cell at $-60 \mathrm{mV}$ with TTX $(0.5 \mu \mathrm{M})$ in the bath, Exn4 induced an inward current $(n=8$; data not shown). The mean peak amplitude of the Exn4-induced current (25.7 \pm $5.4 \mathrm{pA}$ ) was reached $\sim 1$ min after peptide application. Recovery was observed after 5-15 min of Exn4 washout.

We performed control experiments with the GLP-1 receptor antagonist $\operatorname{Exn}_{9-39}$ (Eng et al., 1992; Raufman et al., 1992) in the bath solution. All of the experiments were done with TTX $(0.5 \mu \mathrm{M})$ in the external solution. $\operatorname{Exn}_{9-39}(1 \mu \mathrm{M})$ was added to the bath 3-7 $\mathrm{min}$ before

concentration dependent, with a mean increased spike rate induced by GLP- 1 of $27.8 \pm 1.2 \%$ at $1 \mu \mathrm{M}$ and $61.3 \pm 13.7 \%$ at 10 $\mu \mathrm{M}$ compared with pretreatment levels $(n=4 ; p<0.05$; ANOVA) (Fig. 1C). No significant effect on spike frequency was detected with 100 nм GLP-1 (Fig. $1 C)(n=5 ; p=0.83$; ANOVA).

Native mammalian GLP-1 is very sensitive to degradation by proteases (Goke et al., 1993; Thorens et al., 1993; Mentlei, 1999; Yamamoto et al., 2002, 2003); for this reason, we additionally evaluated the effect of the protease-resistant long-acting GLP-1 receptor agonist Exn4 (Eng et al., 1992; Goke et al., 1993; Gallwitz et al., 2000) on the frequency of action potentials in hypocretin neurons. Exn $4(1 \mu \mathrm{M})$ induced a robust depolarization of the membrane potential and increased the firing rate of hypocretin neurons (Fig. 2A). The time course of the Exn4 effect is shown in Figure $2 B$. These GLP-1 receptor agonist actions were dose dependent, as revealed by the concentration-response analysis (Fig. $2 C)$. Lower doses of Exn4 (10 nM) did not significantly affect the firing rate of hypocretin neurons $(4.8 \pm 5.9 \%$ increase in the spike frequency in comparison with the control; $n=5 ; p=0.50$; ANOVA), whereas $0.1,1$, and $10 \mu \mathrm{M}$ doses of Exn 4 significantly increased firing $(n=5 ; p<0.05$; ANOVA). Together, these results are consistent with the view that the activation of GLP-1 receptors excites hypocretin neurons.

\section{Direct actions of the GLP-1 receptor agonist in hypocretin neurons \\ G-protein-dependent direct action of GLP-1}

The excitatory effect of the GLP-1 receptor activation described above might be explained by direct actions on membrane properties or by indirect modulation of the excitatory synaptic inputs to hypocretin neurons. We first evaluated the direct actions of $1 \mu \mathrm{M}$ Exn 4 in the presence of TTX in the bath. When $0.5 \mu \mathrm{M}$ TTX was applied to the recorded cell under current clamp, a complete suppression of spontaneous action potentials was observed, consistent with the idea that action potentials in hypo-
Exn4 application. In the presence of $\operatorname{Exn}_{9-39}$, Exn4 did not depolarize the membrane potential of hypocretin cells (Fig. $3 A$, trace $2)$. In nine cells tested under these conditions, Exn4 ( $1 \mu \mathrm{M})$ shifted the membrane potential by $0.7 \pm 1.4 \mathrm{mV}$, a nonsignificant effect (Fig. $3 B)(p>0.05$; ANOVA followed by a Bonferroni procedure for multiple comparisons). These results suggest that the direct depolarizing Exn 4 actions are dependent on the specific activation of GLP-1 receptors in hypocretin neurons.

GLP-1 receptors have been suggested to couple to the $G_{s}-$ mediated signal transduction pathway (Drucker et al., 1987). To address this issue, we studied the GTP dependence of the Exn4 depolarizing effects by using the nonhydrolyzable GDP analog GDP $\beta S$ in the recording pipette. These experiments were performed in the presence of TTX $(0.5 \mu \mathrm{M})$ to block spikedependent synaptic activity, and AP-5 $(50 \mu \mathrm{M}), \mathrm{CNQX}(10 \mu \mathrm{M})$, and BIC $(30 \mu \mathrm{M})$ to reduce the possibility of detecting an Exn4 effect on presynaptic glutamate and/or GABA terminals. After 5-10 min of dialysis and with GDP $\beta S$ included in the pipette solution, Exn4 did not evoke significant depolarizing responses in hypocretin cells (Fig. $3 A$, trace $3 ; B$ ) (change in membrane potential, $1.5 \pm 0.9 \mathrm{mV} ; n=6 ; p=0.74$; ANOVA). These experiments confirm that hypocretin cells express functional GLP-1 receptors on their somatodendritic region and that GDP $\beta S$ blocks the actions of Exn4, suggesting that activation by Exn4 depolarizes the membrane potential of hypocretin neurons in a GTP-dependent manner, acting via G-proteins.

\section{$\mathrm{Na}^{+}, \mathrm{K}^{+}$, and $\mathrm{Ca}^{2+}$ channels}

To study the $\mathrm{Na}^{+}$contribution to the Exn4-induced depolarization in hypocretin neurons, we performed experiments in which $\mathrm{NaCl}$ was replaced by an equimolar concentration of choline chloride in the bath solution in the presence of TTX (Shen and North, 1992; Liu et al., 2002). When choline was substituted for sodium, the Exn4-induced depolarization was almost completely 
A

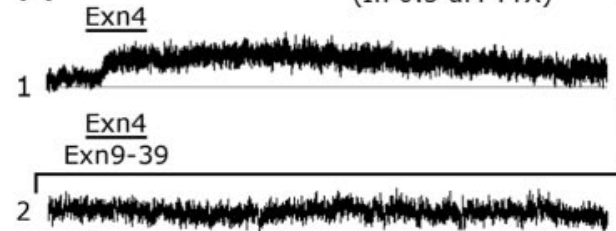

with GDP $\beta S$ in pipette

Exn4

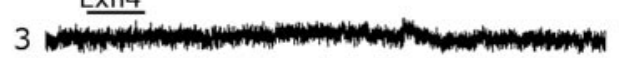

in $\mathrm{Na}^{2+}$ free ACSF Exn4

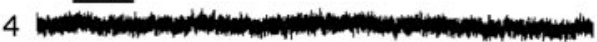

$10 \mathrm{mv}$

$1 \mathrm{~min}$
B

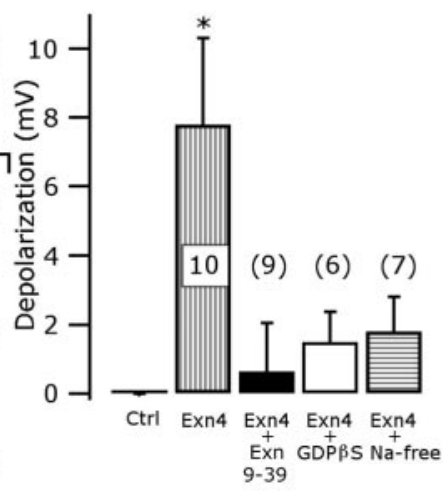

C
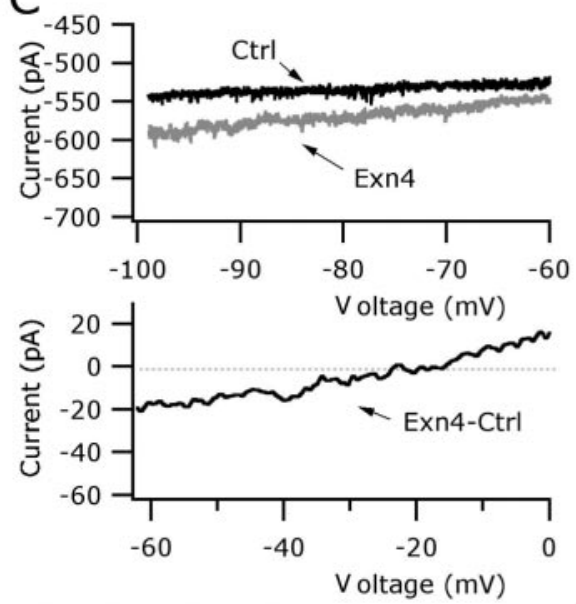
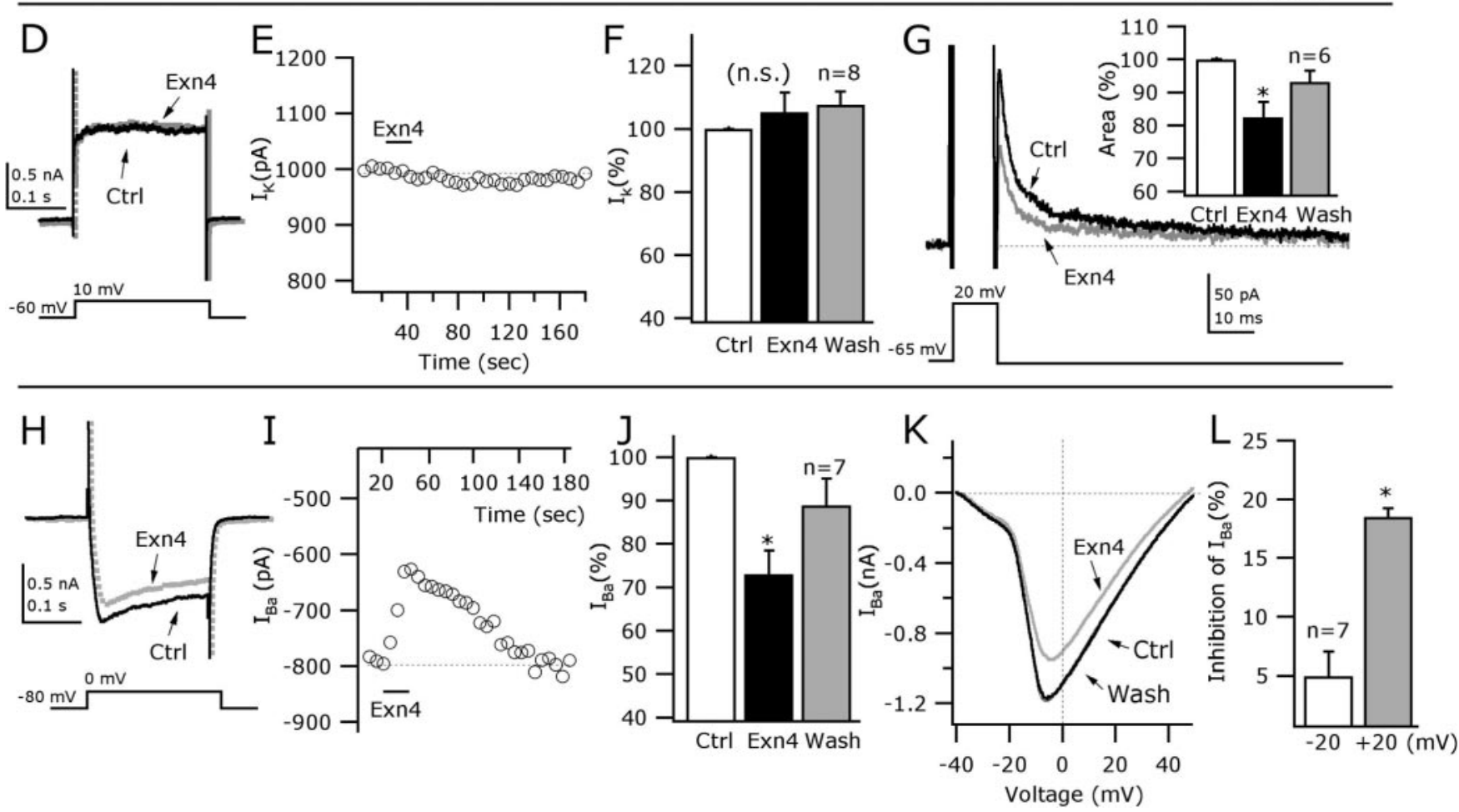

Figure 3. Direct actions of GLP-1 agonist on hypocretin neurons. A, Trace 1, With $0.5 \mu \mathrm{m}$ TTX in the bath, Exn 4 depolarized the hypocretin cell membrane potential. Trace 2 , In the presence of the GLP-1 receptor antagonist Exn ${ }_{9-39}$ in the external solution, Exn4 failed to depolarize the membrane potential. Trace 3, The depolarizing actions of Exn4 were blocked by intracellular GDP $\beta$ S. Trace 4, When extracellular $\mathrm{NaCl}$ was replaced by an equimolar concentration of choline chloride, the depolarizing effects of Exn4 were depressed. B, Bar graph summarizing the Exn4 action on the membrane potential in normal, Exn ${ }_{9-39}$-containing ACSF, low intracellular GTP, and Na ${ }^{+}$-free extracellular conditions. C, Exn4 (1 $\left.\mu \mathrm{M}\right)$ induced an inward current at voltages between -100 and $-60 \mathrm{mV}$ (top graph). The Exn4-induced current showed a reversal potential consistent with a nonspecific cationic conductance (trace from one cell shown in bottom graph). $D-F$, Exn 4 did not evoke a detectable change on potassium currents activated by a voltage step from -80 to $0 \mathrm{mV}$ for $200 \mathrm{msec}$. n.s., Not significant. G, Exn4 depressed afterhyperpolarization currents in hypocretin neurons. In the presence of Exn4, the time integral of $I_{\text {AHP }}$ was reduced by $17.5 \%$ (bar graph). $H-L$, Exn 4 depressed calcium currents in hypocretin neurons. $H$, Exn 4 depressed the current responses evoked by a voltage step from -80 to $0 \mathrm{mV}$ for $200 \mathrm{msec}$. The time course and mean effect of Exn 4 on calcium currents are shown in / and $J$, respectively. ${ }^{*} p<0.05$. $K$, Current response in the presence and the absence of Exn 4 in a typical hypocretin neuron after a voltage ramp from -40 to $+50 \mathrm{mV}$. L, When the relative inhibitory effect of Exn 4 on calcium currents was compared at -20 and +20 $\mathrm{mV}$, a significant difference was detected suggesting that the GLP-1 agonist actions were voltage dependent. Ctrl, Control; Wash, washout. *Statistically significant, $p<0.05$.

abolished in all of the cells tested (Fig. $3 A$, trace $4 ; B)(n=7)$. With choline chloride in the extracellular solution $\left(\mathrm{Na}^{+}\right.$-free solution), Exn 4 changed the membrane potential by only $1.8 \pm 1.1$ $\mathrm{mV}(p=0.76$; ANOVA; not significant). When Exn4 depolarizing effects in the presence of $\mathrm{NaCl}$ or choline chloride in the bath were compared, a statistically significant difference was detected, suggesting that the Exn 4 actions on the membrane potential were primarily dependent on extracellular $\mathrm{Na}^{+}(p<0.05$; ANOVA).

Some excitatory peptidergic sodium-dependent actions have been associated with activation of nonspecific cationic conductances (Liu et al., 2002; Yang et al., 2004). As indicated above, Exn4 induced an inward current when hypocretin cells were held at $-60 \mathrm{mV}$ under voltage clamp. To determine the reversal potential of this Exn4-induced current, slow voltage ramp protocols (from -100 to $0 \mathrm{mV}$ for $5 \mathrm{sec}$ ) were delivered to the hypocretin cells. These experiments were done in the presence of TTX (0.5 $\mu \mathrm{M})$ in the bath and using Cs-based pipette solution to block the voltage-dependent $\mathrm{K}^{+}$currents that could be activated by these 
depolarizing protocols. The application of Exn4 resulted in a consistent inward current $(n=5)$ (Fig. 3C, top graph), which showed a mean reversal potential near $-28.4 \pm 3.1 \mathrm{mV}(n=5)$ (Fig. 3C, bottom graph), consistent with a nonselective cationic current. In additional experiments, we tested a nominally calcium-free-high-magnesium (5 $\mathrm{mm}$ ) extracellular solution to evaluate the extracellular calcium contribution to the Exn4induced excitation in hypocretin cells. In the $\mathrm{Ca}^{2+}$-free-high$\mathrm{Mg}^{2+}$ ACSF, we still observed the Exn4-induced current in hypocretin cells ( $n=6$; data not shown). No decrease in the size of the Exn4-induced current was detected under these conditions, consistent with the view that Exn4 alters a nonselective cationic conductance in hypocretin cells (Formenti et al., 2001; Liu et al., 2002).

To determine whether Exn4 might modulate voltagedependent potassium currents $\left(I_{\mathrm{K}}\right)$, we studied the current responses of hypocretin neurons after a voltage step from -60 to $+10 \mathrm{mV}$ (Gao and van den Pol, 2001). All of these experiments were done in the presence of TTX $(0.5 \mu \mathrm{M})$ and $\mathrm{CdCl}_{2}(200 \mu \mathrm{M})$ in the bath to block the voltage-dependent sodium and calcium channels, respectively. The application of Exn4 to the bath did not significantly modify the $\mathrm{K}^{+}$current, as shown in the traces of Figure 3D. A time course graph showing the lack of Exn 4 effect on the peak $I_{\mathrm{K}}$ is presented in Figure 3E. In the presence of Exn4, the normalized amplitude of potassium currents were changed by $5.4 \pm 6.2 \%$ compared with the control levels, a nonsignificant effect (Fig. $3 F)(n=8 ; p=0.81$; ANOVA). Additionally, the modulation of net whole-cell $\mathrm{K}^{+}$currents was studied with voltage ramp protocols from -100 to $+40 \mathrm{mV}$ in the presence of TTX and $\mathrm{CdCl}_{2}$ in the bath. Under these conditions, the application of $\operatorname{Exn} 4(1 \mu \mathrm{M})$ did not modify the current response of eight hypocretin cells tested (data not shown), suggesting that the activation of GLP-1 receptors does not induce any detectable effect on the voltage-dependent $\mathrm{K}^{+}$currents studied.

Another important determinant of the excitability of many neurons is the afterhyperpolarization (AHP), a hyperpolarizing shift in the membrane potential at the end of an action potential (Sah, 1996). Some of the $\mathrm{K}^{+}$current that underlies this hyperpolarization of the membrane potential is mediated by voltageinsensitive $\mathrm{Ca}^{2+}$-activated $\mathrm{K}^{+}$channels and may be modulated by a number of neurotransmitters, including some agonists of $\mathrm{G}_{\mathrm{s}}$-protein-coupled receptors (Stocker et al., 1999). To study the possible Exn 4 modulation of hyperpolarizing currents $\left(I_{\mathrm{AHP}}\right)$ in hypocretin neurons, we used voltage-clamp protocols holding the cells at $-65 \mathrm{mV}$. The $I_{\mathrm{AHP}}$ was detected after a voltage step from the holding potential to $+20 \mathrm{mV}$ for $10 \mathrm{msec}$ (Fig. $3 G$, bottom). This protocol has been reported to induce a single unclamped action potential (Faber and Sah, 2002), allowing us to study in a quantitative manner the currents underlying singlespike hyperpolarization. After the voltage step, an outward current was detected with a mean amplitude of $93.4 \pm 4.7 \mathrm{pA}(n=6)$ (Fig. 3G). The application of Exn4 to the bath resulted in a consistent decrease in the time integral of the $I_{\mathrm{AHP}}$ with no evident change in its kinetics. In the presence of Exn4 $(1 \mu \mathrm{M})$, the time integral of the $I_{\mathrm{AHP}}$ was reduced by $17.5 \pm 4.5 \%$ compared with the pretreatment value, a statistically significant effect (Fig. $3 G$, bar graph) ( $n=6 ; p<0.05$; ANOVA). Together, these experiments suggest that the activation of GLP-1 receptors may increase the activity of hypocretin neurons, in part by reduction of the AHP current in these cells.

We also evaluated the Exn 4 actions on voltage-dependent calcium currents, using $\mathrm{CsCH}_{3} \mathrm{SO}_{3}$ pipettes. In these experiments, TEA-Cl (40 mM)-containing ACSF was used as the extracellular solution to inhibit potassium currents (the same amount of $\mathrm{NaCl}$ was removed to preserve the osmolarity in the bath), $\mathrm{BaCl}_{2}$ was substituted for $\mathrm{CaCl}_{2}$ to increase the conductance at the calcium channels, and the voltage-dependent sodium currents were blocked by addition of TTX $(0.5 \mu \mathrm{M})$ to the bath. To activate the $I_{\mathrm{Ba}}$, a voltage step from -80 to $0 \mathrm{mV}$ for $200 \mathrm{msec}$ was delivered to the hypocretin cells (Fig. $3 \mathrm{H}$, bottom). Under these conditions, the application of Exn 4 resulted in a consistent decrease in the $I_{\mathrm{Ba}}$, as shown in the representative traces of Figure $3 H$ (also $I, J$ ). The time course of the Exn 4 actions on $I_{\mathrm{Ba}}$ is presented in Figure 3I; the maximum effect was reached $\sim 30 \mathrm{sec}$ after peptide application. In seven cells tested, Exn 4 decreased the $I_{\mathrm{Ba}}$ by $27 \pm 5.4 \%$, a statistically significant effect (Fig. $3 J)(p<0.05$; ANOVA). Application of $\mathrm{CdCl}_{2}(200 \mu \mathrm{M})$ to the recorded cells resulted in a complete abolition of the current response to the voltage steps, confirming that they were attributable to the activation of calcium channels ( $n=7$; data not shown). We next evaluated the voltage dependence of the Exn 4 effects on the calcium channels. To address this issue, a voltage ramp command (from -60 to $+50 \mathrm{mV}$ for 100 or $300 \mathrm{msec}$ ) was delivered to the hypocretin cell, and the current responses in the presence and the absence of Exn4 were determined. The presence of Exn 4 in the bath resulted in a consistent decrease in the current response of the hypocretin cells after the voltage ramp protocol (Fig. $3 K$ ). The relative effects of Exn 4 on $I_{\mathrm{Ba}}$ showed some voltage dependence as suggested by the comparison of the Exn 4 effect at potentials of -20 and $+20 \mathrm{mV}$ (Fig. $3 K, L)(n=6 ; p<0.05$; ANOVA). Together, these results support the view that the activation of GLP-1 receptors modulates, in a voltage-dependent manner, calcium channels in hypocretin cells.

\section{GLP-1 enhances excitatory synaptic transmission in hypocretin neurons}

Parallel to their direct actions on the membrane properties, the activation of GLP-1 receptors might modulate the synaptic inputs to the hypocretin cells. To address this question, we first evaluated the effect of Exn4 on the frequency of the spontaneous synaptic currents in hypocretin cells. Whole-cell voltage-clamp and $\mathrm{KMeSO}_{4}$ pipettes were used in these experiments. Cells were held at $-60 \mathrm{mV}$. Under these conditions, Exn4 (1 $\mu \mathrm{M})$ reversibly increased the frequency of the postsynaptic currents in six cells tested, as shown in Figure $4 A$. These Exn 4 actions were attributable to the GLP-1 receptor activation; in the presence of the GLP-1 receptor antagonist $\operatorname{Exn}_{9-39}(1 \mu \mathrm{M})$ in the external solution, no effect of Exn4 on the PSC frequency was detected (Fig. $4 A$, filled circles). Raw traces showing the typical Exn4 effect on the frequency of the PSCs in normal and $\operatorname{Exn}_{9-39}$-containing ACSF are presented in Figure 4, $B$ and $C$, respectively. The application of $\mathrm{Exn}_{9-39}$ to the recorded cells did not alter the PSC frequency, suggesting a lack of tonic GLP-1 receptor activation (Fig. $4 D)(n=6 ; p>0.05$; ANOVA and Bonferroni post hoc test). In $1 \mu \mathrm{M}$ Exn 4 , the frequency of PSCs increased by $23.9 \pm 8.3 \%$ compared with the pretreatment control level (range, 13.9-41.9\%) (Fig. 4D). This effect was reversible and statistically significant $\left(n=11 ; p<0.05\right.$; ANOVA). With $\operatorname{Exn}_{9-39}$ in the bath, Exn4 changed the PSC frequency by $3.4 \pm 2.3 \%$, a nonsignificant effect (Fig. $4 D)(n=9 ; p>0.05$; ANOVA and Bonferroni post hoc test). These results are consistent with the view that specific activation of GLP-1 receptors can indirectly alter the activity of hypocretin neurons by increasing transmitter release from axons in synaptic contact with hypocretin neurons.

To test the hypothesis that the activation of GLP-1 receptors enhances the glutamate-mediated synaptic inputs to hypocretin 
A

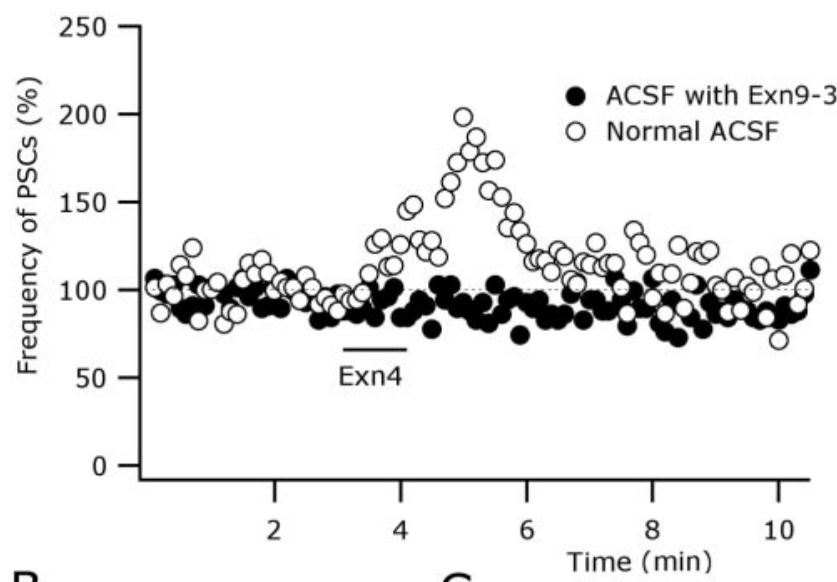

B
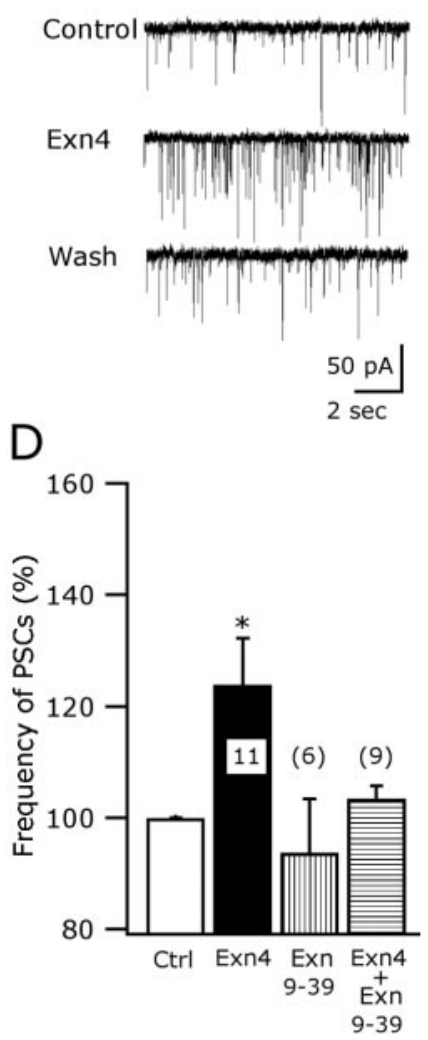

E

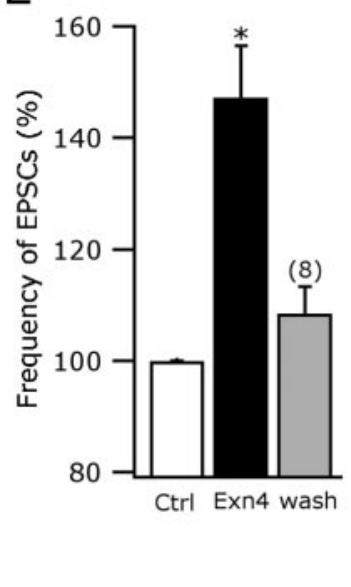

Figure 4. GLP-1 modulates excitatory synaptic inputs to hypocretin neurons. A, Time course of Exn4 effects on the frequency of hypocretin postsynaptic currents in normal (unfilled circles) and Exn $_{9-39}$-containing (filled circles) ACSF. In this experiments, the cells were held at -60 $\mathrm{mV} . \mathrm{B}$, Raw traces show the excitatory effect of Exn4 on the PSC frequency. C, With the GLP-1 receptor antagonist in the bath, Exn4 failed to increase the PSC frequency. D, This bar graph shows the mean effect of Exn4, Exn ${ }_{9-39}$, and Exn 4 plus Exn ${ }_{9-39}$ on the PSC frequency. E, In the presence of $30 \mu \mathrm{M} \mathrm{BIC}$ in the bath and using $\mathrm{KMeSO}_{4}$ pipettes, EPSCs were recorded. Exn4 increases the EPSC frequency, as shown in this bar graph. *Statistically significant. Ctrl, Control; Wash, washout.

neurons, we evaluated the effect of Exn4 on the frequency of the EPSCs. Recordings were done in voltage-clamp mode holding the cells at $-60 \mathrm{mV}$. To selectively isolate the EPSCs, we bath applied the $\mathrm{GABA}_{\mathrm{A}}$ receptor antagonist BIC $(30 \mu \mathrm{M})$. Under these conditions, Exn $4(1 \mu \mathrm{M})$ reversibly enhanced the frequency of EPSCs, as shown in Figure $4 E$. One micromolar Exn 4 significantly increased the EPSC frequency by $47.2 \pm 9.3 \%(n=8 ; p<0.05$;
ANOVA). After 5-10 min of peptide washout, the EPSC frequency returned to the control level (Fig. $4 E$ ). To confirm the glutamatergic nature of these excitatory currents, we then bath applied the AMPA and NMDA glutamate receptor antagonists CNQX $(10 \mu \mathrm{M})$ and AP-5 $(50 \mu \mathrm{M})$, respectively $(n=7$; data not shown). After glutamate receptor blockade, a complete suppression of the synaptic activity was detected in all of the cells tested, suggesting that most of the postsynaptic excitatory currents in hypocretin cells are attributable to glutamate actions on their ionotropic receptors ( $n=7$; data not shown). The effect of the native GLP-1 on the frequency of EPSCs was also evaluated. The addition of $1 \mu \mathrm{M}$ GLP- 1 to the bath resulted in a substantial and reversible increase in the EPSC frequency (data not shown). The frequency of the EPSCs increased by $34 \pm 3.5 \%$ compared with the pretreatment levels, a statistically significant effect $(n=7 ; p<$ 0.05 ; ANOVA). Together, our data show that the activation of GLP-1 receptors indirectly excites hypocretin neurons by increasing the excitatory, glutamate-mediated, tone onto these neurons.

\section{Presynaptic modulation of excitatory transmission by GLP-1 agonists}

To further evaluate the actions of GLP-1 and Exn4 on the glutamatergic axon terminals innervating hypocretin cells, we used TTX $(0.5 \mu \mathrm{M})$ in the bath solution, and recorded the miniature EPSCs (mEPSCs) in the presence of $30 \mu \mathrm{M}$ BIC. When AP-5 and CNQX were added to the medium, all of the excitatory miniature activity was abolished, confirming that these events are attributable to spontaneous glutamate release onto the recorded cells ( $n=7$; data not shown). Exn4 increased the frequency of the miniature excitatory activity (Fig. $5 A, B$ ). In some cells (Fig. 5A), we applied Exn4 twice to confirm its excitatory effects on the mEPSC frequency. Both the first and second application of Exn4 evoked an increase in the frequency of mEPSCs. The Exn4 effects were reversible, because the frequency of mEPSCs returned to pretreatment levels after 5-10 min of peptide washout (Fig. $5 C$ ). In five cells tested, Exn4 evoked a mean increase of $36.3 \pm 10.7 \%$ in the mEPSC frequency $(n=5 ; p<0.05$; ANOVA). We further asked whether Exn 4 could modulate the mEPSC amplitude. To address this question, the cumulative fractions of the amplitude in control and Exn4 conditions were compared. KolmogorovSmirnov analysis showed no significant change in the cumulative fractions of the amplitude after Exn4 $(1 \mu \mathrm{M})$ application in the five cells tested ( $p>0.05$; Kolmogorov-Smirnov test) (Fig. 5D). Exn4 had no effect on mean mEPSC amplitude. The mean mEPSC amplitude was $24.7 \pm 3.5,25.7 \pm 2.1$, and $24.1 \pm 2.9 \mathrm{pA}$ in control, Exn4, and recovery conditions, respectively (ANOVA analysis; $p=0.87$ ).

Additional experiments evaluating the effect of GLP-1 on both the mEPSC frequency and amplitude were conducted. Similar to Exn4, GLP-1 (1 $\mu \mathrm{M})$ significantly enhanced the mEPSC frequency by $22.8 \pm 5.6 \%$ (Fig. $5 E)(n=8 ; p<0.05$; ANOVA). After washout of the peptide, the frequency of the mEPSCs dropped back to control levels (Fig. 5E). Exn4 did not evoke any significant change in the cumulative distribution of the mEPSC amplitude in eight of eight cells (Fig. $5 F)(n=8 ; p>0.05$; Kolmogorov-Smirnov).

Because all of the excitatory synaptic activity was abolished by bath addition of the selective glutamate receptor antagonists AP-5 and CNQX, our results are consistent with the view that the activation of the GLP-1 receptors modulates the release of glutamate onto hypocretin cells, primarily by enhancing release from 


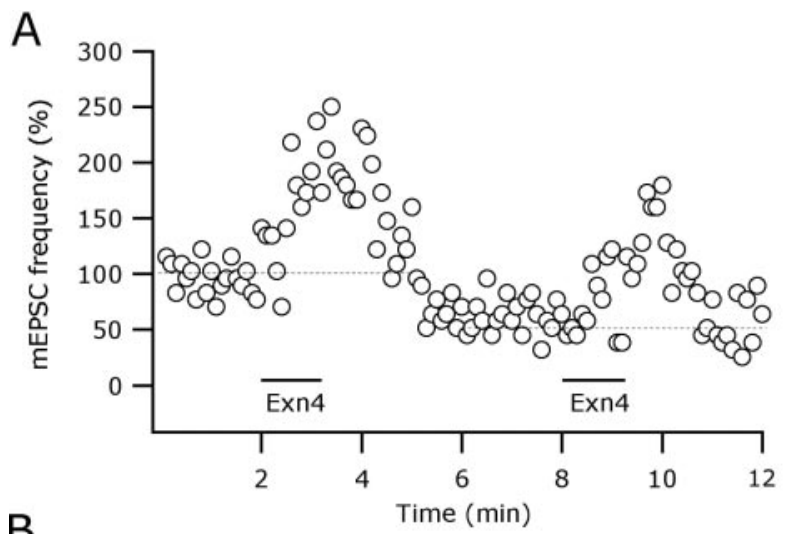

B
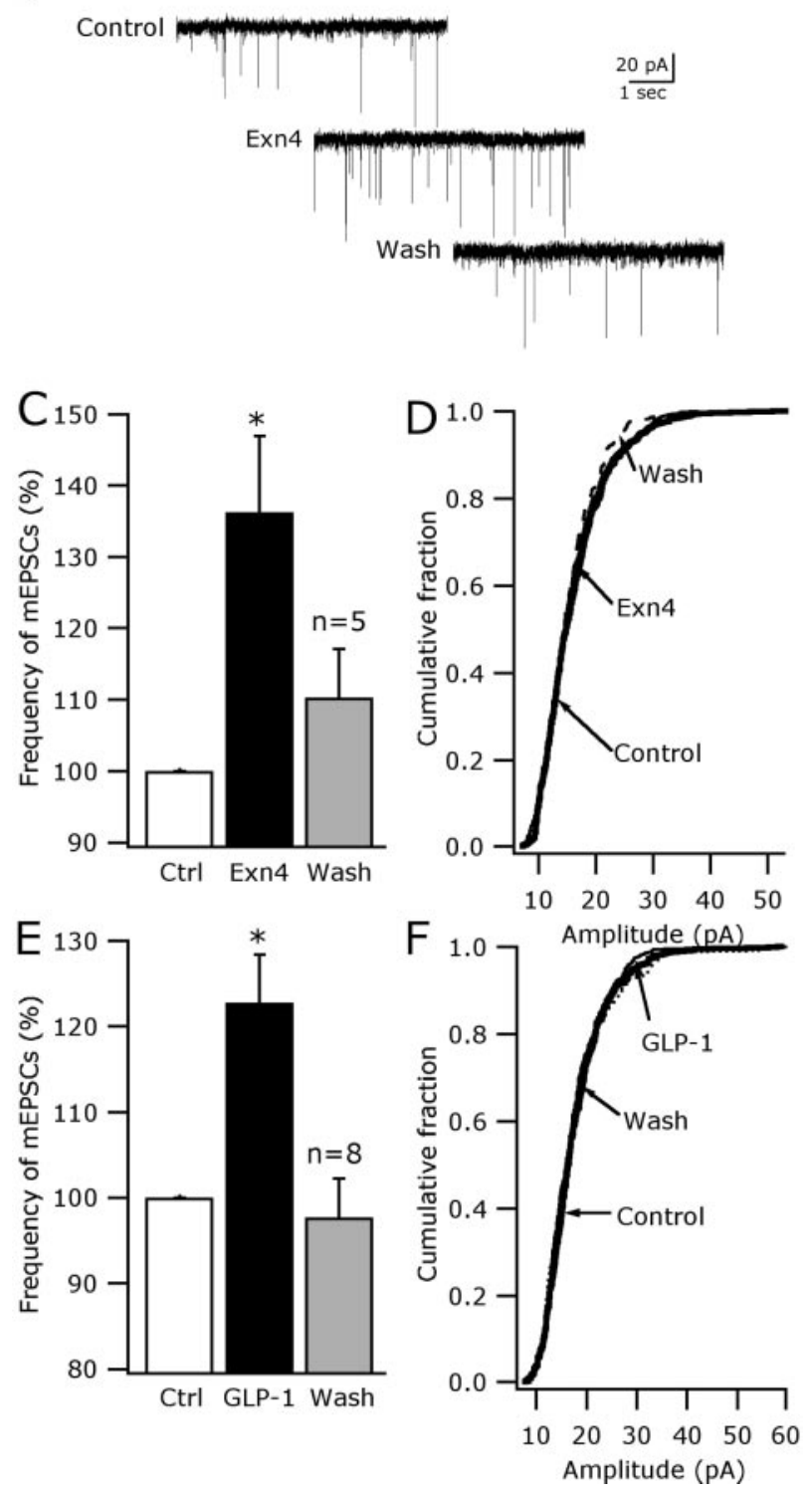

Figure 5. Presynaptic modulation of glutamate release by GLP-1 receptor agonists. A, Exn4 enhanced the frequency of $\mathrm{mEPSC}$. In this particular case, the GLP-1 agonist was applied twice to the recorded cell, evoking repeatable increases in the frequency of mEPSCs. B, Raw traces showing the excitatory effect of Exn4 on the frequency of mEPSCs. C, This bar graph shows the mean effect of Exn4 on the mEPSC frequency. D, The application of Exn4 to the bath failed to evoke a change in the cumulative distribution of the mEPSC amplitude in five cells tested. $E$, GLP-1 also enhanced the mEPSC frequency in hypocretin neurons, but did not modify the CUmulative distribution of the mEPSC s amplitude ( $F)$. ${ }^{*}$ Statistically significant. Ctrl, control; Wash, washout. the presynaptic glutamatergic terminals that innervate hypocretin neurons.

\section{Exendin-4 actions on inhibitory synaptic inputs to hypocretin cells}

Most of the inhibitory synaptic transmission in the hypothalamus appears to be mediated by GABA (Decavel and van den Pol, 1990); we next studied the GLP-1 receptor modulation of the inhibitory, GABA-dependent, synaptic input to hypocretin neurons. AP-5 $(50 \mu \mathrm{M})$ and CNQX $(10 \mu \mathrm{M})$ were bath-applied to selectively suppress the glutamatergic synaptic transmission in hypocretin cells. To identify the IPSCs, KCl-filled pipettes were used. Under these conditions, IPSCs were detected as inward currents when the cells were held at $-60 \mathrm{mV}$. Application of $1 \mu \mathrm{M}$ Exn4 resulted in an increase in the frequency of the IPSCs in hypocretin neurons (Fig. 6A, raw traces). The Exn4 effect on IPSC frequency was reversible, because recovery was observed after peptide washout (Fig. 6B). The frequency of IPSCs was significantly increased by $26.4 \pm 7.6 \%$ after Exn 4 and returned to control levels when the peptide was washed out $(n=5 ; p<0.05$; ANOVA). The inhibitory activity was completely abolished by bicuculline $(30 \mu \mathrm{M})$, confirming that it is attributable to the activation of $\mathrm{GABA}_{\mathrm{A}}$ receptors $(n=8$; data not shown). These results support the idea that GLP-1 receptors modulate the inhibitory, $\mathrm{GABA}_{\mathrm{A}}$ receptor-dependent, synaptic inputs to hypocretin neurons.

To test whether Exn4 acted at the presynaptic GABAergic axon innervating hypocretin neurons, we recorded miniature IPSCs (mIPSCs) in the presence of $0.5 \mu \mathrm{M}$ TTX to block the spike-dependent transmitter release, and AP-5 (50 $\mu \mathrm{M})$ and CNQX $(10 \mu \mathrm{M})$ to block the excitatory, ionotropic glutamate receptor-mediated, inputs to hypocretin cells. When Exn4 was applied to the bath, a significant and reversible increase in the mIPSC frequency was detected (Fig. $6 D)(n=4 ; p<0.05$; ANOVA). The frequency of mIPSCs was enhanced by $42.5 \pm$ $14.3 \%$ in the presence of the GLP-1 agonist, returning to the control levels after Exn4 washout. Changes in the frequency of the miniature postsynaptic potentials have been taken as indications for presynaptic site modulation (Bekkers and Stevens, 1995). Additionally, we evaluated the Exn 4 effects on the mIPSC amplitude. In the presence of $\operatorname{Exn} 4(1 \mu \mathrm{M})$, the cumulative distributions of the amplitude were significantly right-shifted in four cells tested, as shown in Figure $6 E(p<0.05$; KolmogorovSmirnov), suggesting that Exn 4 may postsynaptically modulate GABAergic actions. Previous studies have shown that G-protein, particularly $G_{s}$, activation can enhance GABA or glycine receptor-activated $\mathrm{Cl}^{-}$channels (Song and Huang, 1990; Brandon et al., 2002), consistent with the present data.

\section{GLP-1 receptor agonist actions on $\mathrm{MCH}$ and PVN neurons} $\mathrm{MCH}$ neurons are found in the $\mathrm{LH}$ near the hypocretin neurons and are postulated to play an important role in energy homeostasis (Qu et al., 1996; Shimada et al., 1998). GLP-1 receptor expression and GLP-1 immunoreactive fibers and boutons have been detected in this hypothalamic region, suggesting a possible role for GLP-1 in the modulation of the MCH neuron activity. To address this issue, we studied the GLP-1 agonist effects on the activity of $\mathrm{MCH}$ neurons in hypothalamic slices of transgenic or AAV-MCH-infected mice that show selective GFP expression in $\mathrm{MCH}$ neurons. We first evaluated the effect of Exn4 on spike frequency and membrane potential under current clamp. As described previously, the MCH neurons show very low or no spontaneous firing under resting conditions (Eggermann et al., 2003; 
Gao et al., 2003; van den Pol et al., 2004). When Exn4 ( $1 \mu \mathrm{M})$ was added to the bath, no detectable change in the firing rate or the membrane potential of $\mathrm{MCH}$ neurons was observed $(n=7 ; p>0.05$; ANOVA) (Fig. 7A, trace 3 ), revealing little direct effect of the GLP-1 agonist on these cells. Similarly, Exn 4 had no effect on the membrane potential in the presence of TTX $(0.5$ $\mu \mathrm{M})$ (Fig. 7A, trace $3 ; B$ ). In contrast, when glutamate $(50 \mu \mathrm{M})$ was applied for control purposes to the recorded cells, a strong depolarization followed by a burst of action potentials was observed in all nine $\mathrm{MCH}$ neurons studied (Fig. $7 A$, trace 2). In the presence of TTX $(0.5 \mu \mathrm{M})$, glutamate (50 $\mu \mathrm{M})$ significantly depolarized the $\mathrm{MCH}$ membrane potential $(12.5 \pm 3.6 \mathrm{mV})$ (Fig. $7 B)(n=8 ; p<0.05$; ANOVA $)$.

We next asked whether GLP-1 agonists might indirectly modulate $\mathrm{MCH}$ neurons. To address this issue, we studied the effect of Exn4 on the frequency of PSCs under voltage clamp, holding the GFPexpressing cells at $-60 \mathrm{mV}$, and using $\mathrm{KMeSO}_{4}$ in the pipette. The application of Exn4 to the slice did not significantly modify the frequency of PSCs in MCH neurons (Fig. $7 C$ ). In the presence of Exn4 in the bath, the normalized PSC frequency was changed by $4.4 \pm 4.9 \%$ compared with the control, a nonsignificant effect $(n=6 ; p>$ 0.05 ; ANOVA). To evaluate the direct Exn4 action on the presynaptic axons innervating $\mathrm{MCH}$ neurons, we determined its actions on the frequency of miniature PSCs (mPSCs) in the presence of TTX $(0.5 \mu \mathrm{M})$ in the bath. Under these conditions, no detectable changes in the frequency or the amplitude of mPSCs were observed after the addition of Exn4 $(1 \mu \mathrm{M})$ to the recorded cells. The frequencies of the mPSC were $96.9 \pm 11.2$ and $95.4 \pm 25.3 \%$ compared with the control $(100 \%)$, in Exn4 and recovery conditions, respectively $(n=5$; $p>0.05$ ) (Fig. 7D). In five cells, we determined the Exn 4 actions on the cumulative distribution of the mPSC amplitude. When the pre- and post-Exn 4 cumulative fractions were compared in these cells, no significant alterations in the cumulative distributions of the mPSC amplitude were detected (Fig. $7 E)(n=5 ; p>0.05$; Kolmogorov-Smirnov). Together, these results suggest that the activation of GLP-1 receptors exerts no detectable effect on the synaptic inputs to $\mathrm{MCH}$.

Additionally, we evaluated the GLP-1 agonist actions on PVN neurons, because high levels of expression of GLP-1 receptors have been reported in this hypothalamic region (Merchenthaler et al., 1999), and in parallel, GLP-1-positive fibers have been found in the PVN (Rinaman, 1999). To determine the effect of the GLP-1 agonist Exn4 on PVN neurons, whole-cell currentclamp experiments were conducted in mouse hypothalamic slices. Under DIC, the PVN was easily identified lateral to the third ventricle. Because a high density of GLP-1 receptors has been detected in the magnocellular subdivision (Merchenthaler et al., 1999), the recordings were done from neurons in the ventrolateral magnocellular region of the PVN.

Exn4 evoked three different types of response in PVN neurons
B

D
Ctrl Exn4 Wash
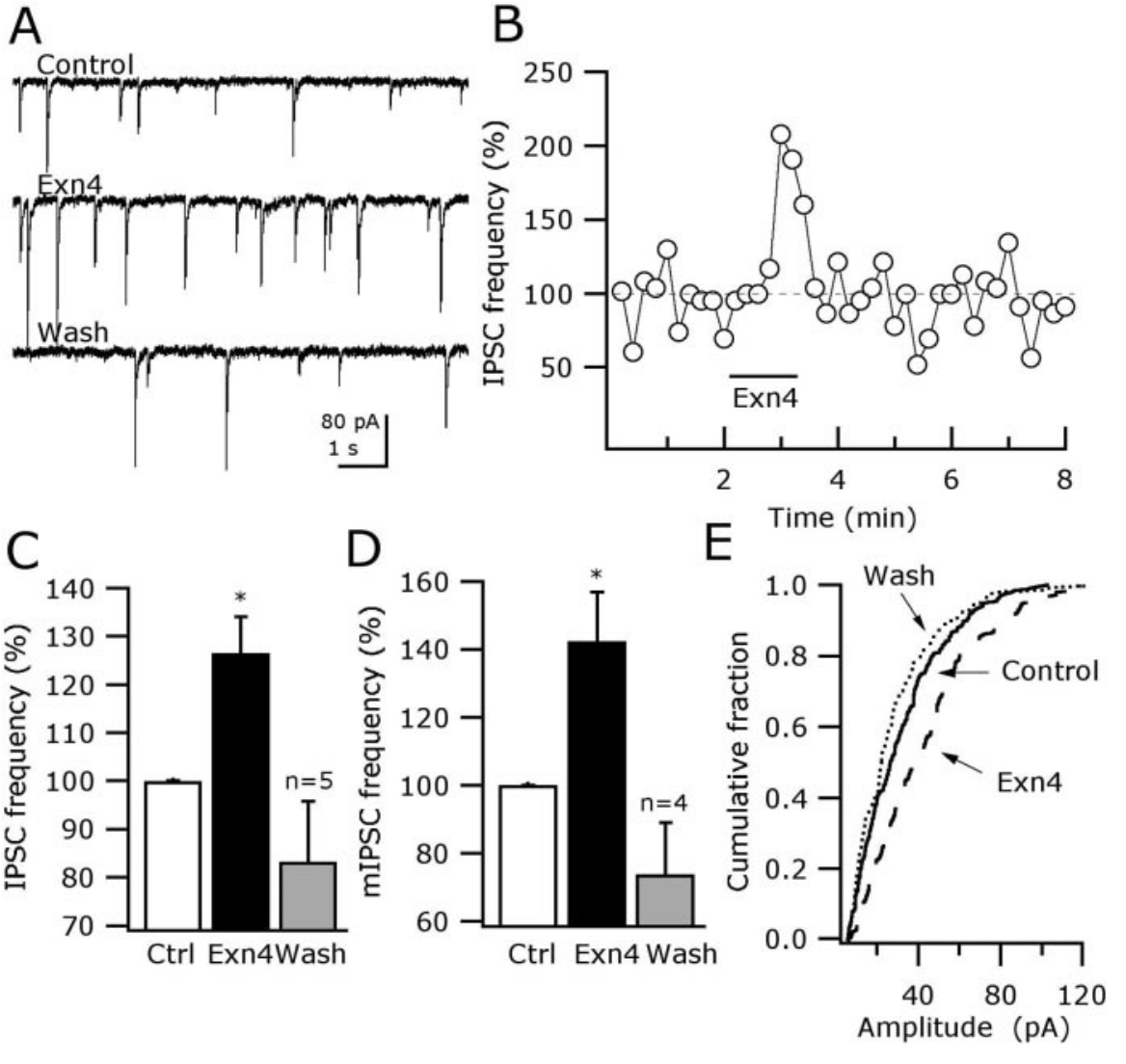

Figure 6. GLP-1 agonist enhances inhibitory, GABA-mediated, synaptic transmission in hypocretin neurons. $A$, Exn4 enhanced currents. $B$, Time course of the Exn4 actions on IPSC frequency. C, Exn4 increased the frequency of IPSCs in five cells tested. D, E, mIPSCs by $42.5 \pm 14.3 \%$ (D). The cumulative distributions of the mIPSCs were also significantly altered in all of the cells tested trl, control; Wash, washout.

(Fig. 7F1-F3). In 12 cells (57.2\%), the application of $1 \mu \mathrm{M}$ Exn4 resulted in a robust, long-lasting depolarization of the membrane potential, followed by an increase in the frequency of action potentials (Fig. 7F1). In these neurons, Exn4 enhanced the firing rate by $35 \pm 7.8 \%$ compared with control (data not shown; $p<$ 0.05; ANOVA). In three neurons (representing 14.3\%), Exn4 depressed the spike frequency of PVN neurons by $43.5 \pm 9.5 \%$ compared with the control pretreatment levels $(p<0.05$; ANOVA). Little or no alteration in the spike frequency or membrane potential after Exn 4 was detected in the remaining six PVN recorded cells $(28.1 \%)$. To determine whether these actions were attributable to direct Exn4 activation of postsynaptic receptors, we conducted additional experiments in the presence of TTX $(0.5$ $\mu \mathrm{M})$ in the bath solution. Under these conditions, stable recordings were obtained from 11 neurons located around the magnocellular portion of the PVN. In five neurons (45\%), depolarizing shifts of the membrane potential were detected after the addition of Exn 4 to the bath (Fig. $7 G$, top trace). The Exn4 application depolarized PVN cells by $7.4 \pm 2.1 \mathrm{mV}$ compared with the resting pretreatment conditions. These effects were reversible, because the membrane potential returned to the control value after peptide washout. ANOVA analysis showed that these Exn4 actions on the membrane potential were statistically significant $(p<$ $0.05)$. In the six remaining cells, no significant change in the membrane potential was detected (Fig. $7 G$, bottom trace). No hyperpolarizing effects of Exn 4 on the membrane potential of PVN neurons were observed in the presence of TTX $(0.5 \mu \mathrm{M})$, 

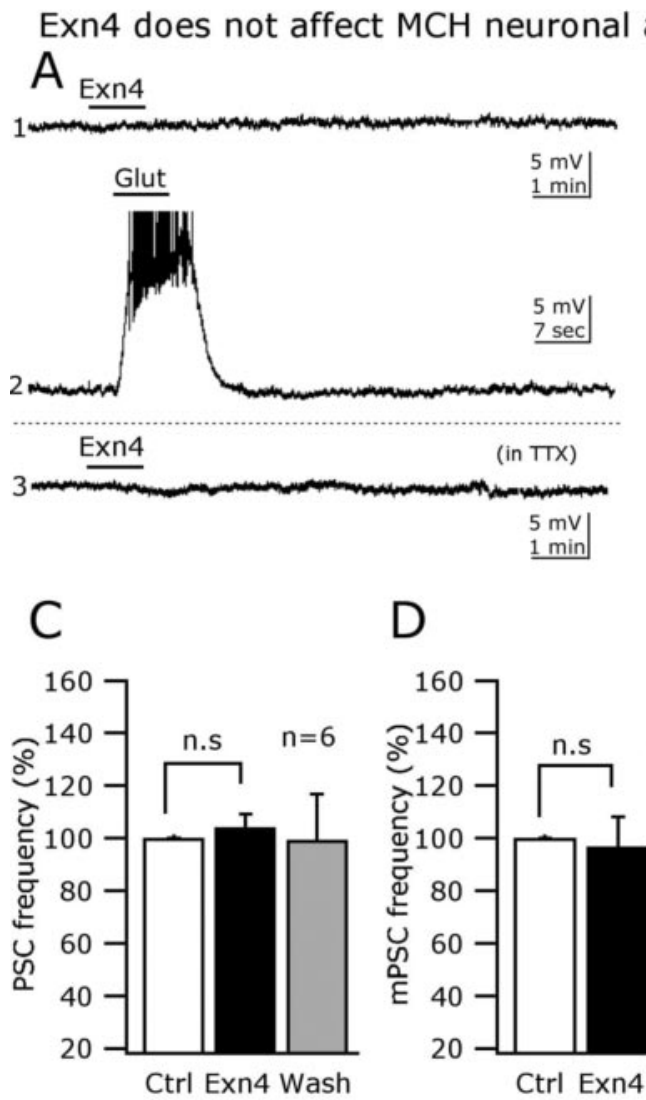

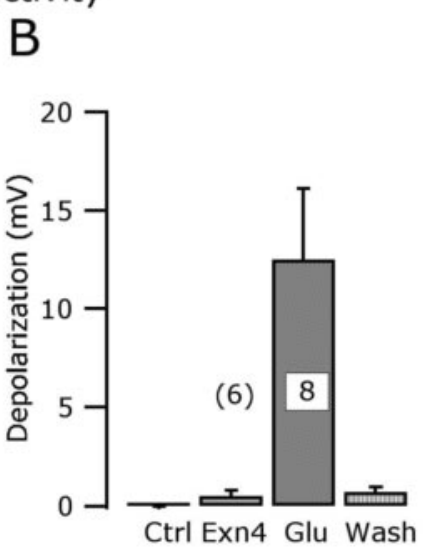

$\mathrm{E}$

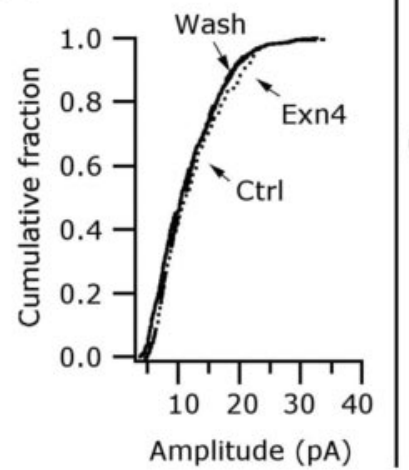

\section{Exn4 actions in PVN neurons} $\mathrm{F}$

1. Excitation

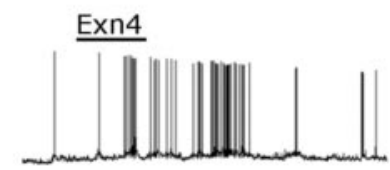

Exn4

2. Inhibition

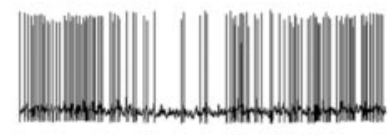

Exn4

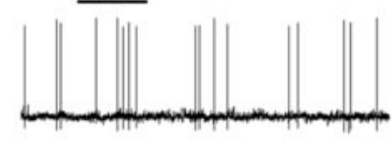

G

In 0.5 uM TTX:

1.

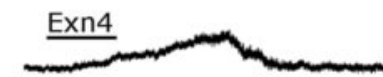

2.

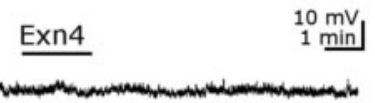

Figure 7. Effects of GLP-1 agonist on MCH and paraventricular hypothalamic neurons. $A$, Trace 1, Exn4 $(1 \mu \mathrm{M})$ did not evoke any detectable change in the firing rate or the membrane potential in an MCH neuron. Trace 2,50 $\mu \mathrm{m}$ glutamate (Glut) induced a robust depolarization followed by a burst of action potentials in an MCH neuron. The action potentials were truncated in this figure. Trace 3 shows the lack of Exn 4 effects on the membrane potential in the presence of the TTX $(0.5 \mu \mathrm{M})$. B, Bar graph showing the effects of Exn 4 and glutamate on the membrane potential of MCH neurons in the presence of $0.5 \mu \mathrm{m}$ TTX in the bath. C, Exn4 showed no effect on the synaptic inputs to MCH neurons, because it did not increase the frequency of PSCs in these cells. D, E, In the presence of TTX $(0.5 \mu \mathrm{M})$ in the bath, Exn4 did not evoke any significant change in the frequency $(D)$ or the amplitude $(E)$ of mEPSCs recorded in MCH neurons. $F$, G, Diverse Exn4 responses were detected in PVN cells. An excitatory (increase in spike frequency) response (F1) was detected in $57 \%$ of the recorded neurons, whereas an inhibitory (depressing in the firing rate) response (F2) was observed in $14 \%$ of the recorded cells. We did not detect any change in the spike frequency or membrane potential in the remaining $28 \%$ of the recorded cells ( $F 3$ ). $G$, In the presence of $0.5 \mu \mathrm{m} T T X$ in the bath, only depolarizing responses were detected in $45 \%$ of the cells (top trace). The remaining cells (bottom trace) did not show a significant change in their membrane potential with Exn4 application. Ctrl, control; n.s., not significant; Wash, washout.

suggesting that the depressing effect on the spike frequency described above might be attributable to an enhancement of the inhibitory synaptic inputs to these PVN neurons.

\section{Discussion}

In this study, we used whole-cell voltage clamp and current clamp to examine the cellular actions of GLP-1 agonists on the activity of hypocretin neurons identified by selective GFP expression in mouse hypothalamic slices. GLP-1 agonists depolarized the membrane potential of hypocretin neurons and increased spike frequency. These excitatory actions on the membrane potential were attributable to direct postsynaptic activation of GLP-1 receptors, dependent on extracellular $\mathrm{Na}^{+}$, mediated by the activation of G-proteins, and blockable by a GLP-1 receptor antagonist, exendin (9-39). GLP-1 also enhanced glutamate release at axon terminals synapsing onto hypocretin cells, in part by activation of presynaptic GLP-1 receptors. PVN neurons were also excited by GLP-1 agonists, consistent with the high levels of GLP-1containing fibers and receptors found here. In contrast, GLP-1 agonists had no effect on identified $\mathrm{MCH}$ neurons in the $\mathrm{LH}$.

\section{GLP-1 presynaptic and postsynaptic excitation of} hypocretin neurons

To the best of our knowledge, GLP-1 actions have not been studied previously at the cellular level in the CNS. We show here that GLP-1 excites LH hypocretin neurons by both postsynaptic and presynaptic mechanisms. Direct depolarizing effects of GLP-1 were evident in the presence of TTX, suggesting the activation of postsynaptic GLP-1 receptors expressed by hypocretin neurons. Our experiment using a nonhydrolyzable GTP (GDP $\beta S$ ) analog in the recording pipette confirmed that the GLP-1 depolarizing action in hypocretin cells were G-protein dependent (Hoosein and Gurd, 1984), and that the receptor-G-protein complex is located on the somatodendritic region of the recorded hypocretin cell.

GLP-1 caused an increase in spike frequency and an associated inward current. The replacement of extracellular sodium with choline strongly depressed or eliminated the direct depolarizing actions of GLP-1. The reversal potential for the inward current was near $-28 \mathrm{mV}$, a potential between the negative $\mathrm{K}^{+}$and the positive $\mathrm{Na}^{+}$reversal potentials. Furthermore, the current was 
not substantially altered by low extracellular calcium, both findings consistent with activation of a nonselective cationic current (Formenti et al., 2001; Liu et al., 2002; Yang et al., 2004). Although nonselective cationic conductances do not appear to have been reported previously in hypocretin neurons, they have been observed in other neurons expressing G-protein-coupled peptide receptors (Kirkpatrick and Bourque, 1995; Liu et al., 2002), including the $G_{s}$ subtype (Yang et al., 2004). One mechanism of GLP-1 actions in non-neuronal cells is the depression of an inward rectifier $\mathrm{K}^{+}$conductance (Light et al., 2002). In hypocretin neurons, we found no evidence for GLP-1 modulation of wholecell $\mathrm{K}^{+}$conductances activated either by voltage steps or by voltage-ramp commands, using protocols typically used to study $\mathrm{K}^{+}$currents, including the inward rectifier subtypes (Sodickson and Bean, 1996; Yang et al., 2004). This suggests that these $\mathrm{K}^{+}$ currents were not the primary mechanism of excitation involved in the modulatory actions of GLP-1 in hypocretin neurons. Another mechanism by which transmitter may regulate neuronal excitability is the modulation of the AHP current (Sah, 1996; Stocker et al., 1999). GLP-1 attenuated the AHP current in hypocretin cells, suggesting that modulation of the $\mathrm{K}^{+}$currents involved in hyperpolarization after an action potential may be one mechanism by which GLP-1 increased spike frequency.

GLP-1 depresses $\mathrm{Ca}^{2+}$ currents in hypocretin neurons. GLP-1 receptors have been suggested to couple to the $G_{s}$ type of G-protein. Activation of $\mathrm{G}_{\mathrm{s}}$-coupled receptors have been reported to enhance $\mathrm{Ca}^{2+}$ currents in many cells (Dolphin, 1998); in addition, several reports have shown that, in some cell types, activation of $\mathrm{G}_{\mathrm{s}}$ may depress $\mathrm{Ca}^{2+}$ currents (Shapiro and Hille, 1993; Zhu and Yakel, 1997), a finding consistent with the data here. A recent report showed that GLP-1 receptors may also couple to $G_{i / o}$ subtypes of G-proteins (Hallbrink et al., 2001). Previous studies have shown depression of calcium currents by activation of $\mathrm{G}_{\mathrm{i} / \mathrm{o}}$ proteins (Gao and van den Pol, 2001). The critical factor for the inhibitory modulation of voltage-dependent calcium channels may be the presence of the G-protein $\beta \gamma$ subunits (Herlitze et al., 1996; Ikeda, 1996). The depression of the calcium current by GLP-1 may be one mechanism by which the amplitude of the calcium-dependent potassium AHP current is attenuated.

In addition to the direct activation of postsynaptic receptors, GLP-1 agonists indirectly activated hypocretin neurons by increasing the frequency of spontaneous EPSCs. These currents were abolished by AMPA and NMDA receptor antagonists, suggesting that GLP-1 enhances the release of glutamate from axon terminals synapsing onto hypocretin cells. GLP-1 agonists increased the frequency of miniature EPSCs with little change in the event amplitude, suggesting that GLP-1 agonists enhance glutamate release by activation of GLP-1 receptors on the presynaptic terminals innervating hypocretin cells. Axons that release glutamate provide the primary excitatory input to hypocretin neurons, and some of these arise locally from excitatory neurons within the LH that might play a role in orchestrating the output of the dispersed hypocretin neurons (Li et al., 2002; AcunaGoycolea et al., 2004); thus, GLP-1 would potentially enhance hypocretin cell activity by enhancing glutamate release.

Whereas hypocretin neurons showed only excitatory responses, PVN neurons showed more heterogeneous responses, consistent with the presence of different types of neurons within the PVN. The primary GLP-1 response of PVN neurons was excitatory, as shown by an increase in spike frequency. A small number of PVN neurons showed a decrease in spike frequency; hypothetically, this inhibition could be attributable to GLP-1mediated excitation of inhibitory interneurons, resulting in a sec- ondary indirect inhibition of other PVN cells. This view is consistent with the finding that, when spike-dependent synaptic activity was blocked with TTX, only depolarizing actions of GLP-1 were found in PVN neurons. Because both hypocretin and paraventricular neurons showed similar excitatory responses, it is probable that other neurons that express the GLP-1 receptor will respond similarly.

$\mathrm{MCH}$ neurons are intermixed, but constitute a group of cells different from the hypocretin neurons within the LH (Elias et al., 1998; Peyron et al., 1998). Mice lacking MCH peptide or its receptors are hypophagic and lean; intracranial $\mathrm{MCH}$ injections increase food intake (Qu et al., 1996; Rossi et al., 1999), suggesting $\mathrm{MCH}$ neurons may participate in energy homeostasis. We found little or no effect of GLP-1 agonists on the activity of identified MCH neurons, supporting the view that GLP-1 actions in the LH are highly selective, affecting hypocretin but not the adjacent $\mathrm{MCH}$ neurons.

\section{Functional considerations}

GLP-1-containing neuronal cell bodies are primarily located in the caudal NTS (Han et al., 1986; Jin et al., 1988), and axons from these cells innervate both the lateral hypothalamus and PVN. The NTS receives a broad spectrum of sensory signals from the gut, carried in part by the subdiaphragmatic vagus nerve; signals include sensory input from liver, stomach, and intestinal receptors (Powley, 2000; Saper et al., 2002; Vrang et al., 2003). These signals may be associated with the homeostatic control of feeding, and possibly involved in initiation or termination of meals (Saper et al., 2002). In addition to release from neurons of the NTS, GLP-1 may also be released from the gut into the vascular system. Although it is possible that LH neurons might be activated by circulating GLP-1, this appears less likely because the large peptide would not pass freely through the blood-brain barrier into the LH; circulating GLP-1 could, however, activate the NTS via axons from the area postrema, which may respond to circulating GLP-1 via a weak blood-brain barrier (Yamamoto et al., 2003). CNS administration of GLP-1 causes a profound inhibition of food intake, suggesting that GLP-1 may be critical for meal cessation (Tang-Christensen et al., 1996; Turton et al., 1996). However, mice with a targeted disruption of the GLP-1 receptor gene have normal body weight and feeding behavior (Scrocchi et al., 1996; Scrocchi and Drucker, 1998), suggesting that GLP-1 may not be critical for the long-term regulation of energy balance. GLP-1 neurons that project to the hypothalamus are activated by interoceptive stress (Rinaman, 1999), and GLP-1 neurons may mediate hypothalamic endocrine and anxiety responses generated by this stress (Seeley et al., 2000; Kinzing et al., 2003). Association of food with GLP-1 administration can lead to conditioned food avoidance, suggesting that GLP-1, at least with high levels, may provide negative cues or an unpleasant sensation that can be associated with food. Negative cues from the viscera may not be related solely to energy homeostasis; cardiac stress signaling to the NTS may also initiate arousal through the hypocretin neurons. Finally, hypocretin neurons project to the area of the GLP-1 cells in the NTS (Peyron et al., 1998) and hypocretin enhances activity of unidentified NTS neurons (Smith et al., 2002), providing potential direct feedback.

GLP-1 neurons in the NTS that project to the PVN increase expression of c-fos (a marker of neuronal activation) after interoceptive stress stimuli that included lithium chloride, bacterial lipopolysaccharides, and cholecystokinin; the excitatory response of PVN neurons to GLP-1 may activate the endocrine response to interoceptive stress (Rinaman, 1999; Seeley et al., 
2000; Kinzing et al., 2003). In addition to responding to GLP-1, PVN neurons also respond to a number of other neuropeptides considered to regulate energy homeostasis (Cowley et al., 1999).

Recent experiments have suggested that hypocretin neurons may regulate arousal that is dependent on the energy state (Yamanaka et al., 2003). In this report, we show that GLP-1 agonists consistently excite hypocretin neurons, suggesting that GLP-1 cells may enhance hypothalamic arousal. Because GLP-1 neurons appear to receive a variety of gut signals involved in the regulation of food intake, GLP-1 effects on hypocretin neurons might be an important substrate for the integration of gut signals relating energy homeostasis with hypothalamic arousal, or for enhancing arousal signaled by visceral or cardiac stress.

\section{References}

Acuna-Goycolea C, Li Y, van den Pol AN (2004) Group III metabotropic glutamate receptors maintain tonic inhibition of excitatory synaptic input to hypocretin/orexin neurons. J Neurosci 24:3013-3022.

Bekkers JM, Stevens CF (1995) Quantal analysis of EPSCs recorded from small numbers of synapses in hippocampal cultures. J Neurophysiol 73:1145-1156.

Brandon NJ, Jovanovic JN, Smart TG, Moss SJ (2002) Receptor for activated C kinase-1 facilitates protein kinase C-dependent phosphorylation and functional modulation of $\mathrm{GABA}_{\mathrm{A}}$ receptors with the activation of G-protein-coupled receptors. J Neurosci 22:6353-6361.

Broberger C, de Lecea L, Sutcliffe JG, Hökfelt T (1998) Hypocretin/orexin and melanin-concentrating hormone-expressing cells form distinct populations in the rodent lateral hypothalamus: relationship to the neuropeptide $\mathrm{Y}$ and Agouti gene-related protein systems. J Comp Neurol 402:460-474.

Borowsky B, Durkin MM, Ogozalek K, Marzabadi MR, DeLeon J, Lagu B, Heurich R, Lichtblau H, Shaposhnik Z, Daniewska I, Blackburn TP, Branchek TA, Gerald C, Vaysse PJ, Forray C (2002) Antidepressant, anxiolytic and anorectic effects of a melanin-concentrating hormone-1 receptor antagonist. Nat Med 8:825-830.

Chemelli RM, Willie JT, Sinton CM, Elmquist JK, Scammel T, Lee C, Richardson JA, Williams SC, Xiong Y, Kisanuki Y, Fitch TE, Nakazato M, Hammer RE, Saper CB, Yanagisawa M (1999) Narcolepsy in orexin knockout mice: molecular genetics of sleep regulation. Cell 98:437-451.

Clements JD, Bekkers JM (1997) Detection of spontaneous synaptic events with an optimally scaled template. Biophys J 73:220-229.

Cowley MA, Pronchuk N, Fan W, Dinulescu DM, Colmers WF, Cone RD (1999) Integration of NPY, AGRP, and melanocortin signals in the hypothalamic paraventricular nucleus: evidence of a cellular basis for the adipostat. Neuron 24:155-163.

Decavel C, van den Pol AN (1990) GABA: a dominant neurotransmitter in the hypothalamus. J Comp Neurol 302:1019-1037.

Dolphin AC (1998) Mechanisms of modulation of voltage-dependent calcium channels by G proteins. J Physiol (Lond) 506:3-11.

Drucker DJ, Philippe J, Mojsov S, Chick WL, Habener JF (1987) Glucagonlike peptide 1 stimulates insulin gene expression and increases cyclic AMP levels in a rat islet cell line. Proc Natl Acad Sci USA 84:3434-3438.

Eggermann E, Bayer L, Serafin M, Saint-Mleux B, Bernheim L, Machard D, Jones BE, Muhlethaler M (2003) The wake-promoting hypocretinorexin neurons are in an intrinsic state of membrane depolarization. J Neurosci 23:1557-1562.

Elias CF, Saper CB, Maratos-Flier E, Tritos NA, Lee C, Kelly J, Tatro JB, Hoffman GE, Ollmann MM, Barsh GS, Sakurai T, Yanagisawa M, Elmquist JK (1998) Chemically defined projections linking the mediobasal hypothalamus and the lateral hypothalamic area. J Comp Neurol 402:442-459.

Eng J, Kleinman WA, Singh L, Singh G, Raufman J-P (1992) Isolation and characterization of exendin-4, and exendin-3 analogue from Heloderma suspectum venom. J Biol Chem 267:7402-7405.

Faber ESL, Sah P (2002) Physiological role of calcium-activated potassium currents in the lateral amygdala. J Neurosci 22:1618-1628.

Formenti A, De Simoni A, Arrigoni E, Martina M (2001) Changes in extracellular $\mathrm{Ca}^{2+}$ can affect the pattern of discharge in rat thalamic neurons. J Physiol (Lond) 535:33-45.

Gallwitz B, Ropeter T, Morys-Wortmann C, Mentlein R, Siegel EG, Schmidt
WE (2000) GLP-1-analogues resistant to degradation by dipeptidylpeptidase IV in vitro. Regul Pept 86:103-111.

Gao XB, van den Pol AN (2001) Melanin concentrating hormone depresses synaptic activity of glutamate and GABA neurons from rat lateral hypothalamus. J Physiol (Lond) 533:237-252.

Gao XB, Ghosh PK, van den Pol AN (2003) Neurons synthesizing melaninconcentrating hormone identified by selective reporter gene expression after transfection in vitro. J Neurophysiol 90:3978-3985.

Goke R, Fehmann HC, Linn T, Schmidt H, Krause M, Eng J, Goke B (1993) Exendin-4 is a high potency agonist and truncated exendin-(9-39)-amide an antagonist at the glucagon-like peptide 1-(7-36)-amide receptor of insulin-secreting $\beta$-cells. J Biol Chem 268:19650-19655.

Hagan JJ, Leslie RA, Patel S, Evans ML, Wattam TA, Holmes S, Benham CD, Taylor SG, Routledge C, Hemmati P, Munton RP, Ashmeade TE, Shah AS, Hatcher JP, Hatcher PD, Jones DN, Smith MI, Piper DC, Hunter AJ, Porter RA, Upton N (1999) Orexin A activates locus coeruleus cell firing and increases arousal in the rat. Proc Natl Acad Sci USA 96:10911-10916.

Hallbrink M, Holmqvist T, Olsson M, Ostenson C-G, Efendic S, Langel U (2001) Different domains in the third intracellular loop of the GLP-1 receptor are responsible for $\mathrm{G} \alpha_{\mathrm{s}}$ and $\mathrm{G} \alpha_{\mathrm{i}} / \mathrm{G} \alpha_{\mathrm{o}}$ activation. Biochim Biophys Acta 1546:79-86.

Han VKM, Hynes MA, Jin C, Towle AC, Lauder JM, Lund PK (1986) Cellular localization of proglucagon/glucagon-like peptide 1 messenger RNAs in the rat brain. J Neurosci Res 16:97-107.

Herlitze S, Garcia DE, Mackie K, Hille B, Scheuer T, Catterall WA (1996) Modulation of $\mathrm{Ca}^{2+}$ channels by G-protein beta gamma subunits. Nature 380:258-262

Hoosein NM, Gurd RS (1984) Human glucagon-like peptide-1 and 2 activates rat brain adenylate cyclase. FEBS Lett 178:83-86.

Ikeda SR (1996) Voltage-dependent modulation of N-type calcium channels by G-protein beta gamma subunits. Nature 380:255-258.

Jin SL, Han VKM, Simmons JG, Towle AC, Lauder JM, Lund PK (1988) Distribution of glucagon-like peptide 1, glucagon, and glicentin in the rat brain: an immunocytochemical study. J Comp Neurol 271:519-533.

Kinzing KP, D'Alessio DA, Herman JP, Sakai RR, Vahl TP, Figueiredo HF, Murphy EK, Seeley RJ (2003) CNS glucagon-like peptide-1 receptors mediate endocrine and anxiety responses to interoceptive and psychogenic stressors. J Neurosci 23:6163-6170.

Kirkpatrick K, Bourque CW (1995) Effects of neurotensin on rat supraoptic nucleus neurons in vitro. J Physiol (Lond) 482:373-381.

Kreymann B, Ghatei MA, Burnet P, Williams G, Kanse S, Diani AR, Bloom SR (1989) Characterization of glucagon-like peptide 1-(7-36) amide in the rat hypothalamus. Brain Res 502:325-331.

Larsen PJ, Tang-Christensen M, Holst JJ, Orskov C (1997a) Distribution of glucagon-like peptide 1 and other preproglucagon-derivated peptides in the rat hypothalamus and brainstem. Neuroscience 77:257-270.

Larsen PJ, Tang-Christensen M, Jessop DS (1997b) Central administration of glucagon-like peptide- 1 activates hypothalamic neuroendocrine neurons in the rat. Endocrinology 138:4445-4455.

Li Y, Gao XB, Sakurai T, van den Pol AN (2002) Hypocretin/orexin excites hypocretin neurons via a local glutamate neuron - a potential mechanism for orchestrating the hypothalamic arousal system. Neuron 36:1169-1181.

Light PE, Fox JE, Riedel MJ, Weeler MB (2002) Glucagon-like peptide-1 inhibits pancreatic ATP-sensitive potassium channels via protein kinase A- and ADP-dependent mechanisms. Mol Endocrinol 16:2135-2144.

Lin L, Faraco J, Li H, Kadotani R, Rogers W, Lin X, Qui X, deJong PJ, Nishino S, Mignot E (1999) The sleep disorder canine narcolepsy is caused by a mutation in the hypocretin (orexin) receptor 2 gene. Cell 98:365-376.

Liu RJ, van den Pol AN, Aghajanian GK (2002) Hypocretins (orexins) regulate serotonin neurons in the dorsal raphe nucleus by excitatory direct and inhibitory indirect actions. J Neurosci 22:9453-9464.

Meeran K, O'Shea D, Edwards CMB, Turton MD, Heath MM, Gunn I, Abusnana S, Rossi M, Small CJ, Goldstone AP, Taylor GM, Sunter D, Steere J, Choi SJ, Ghatei MA, Bloom SR (1999) Repeated intracerebroventricular administration of glucagon-like peptide-1-(7-36) amide or exendin-(939) alters body weight in the rat. Endocrinology 140:244-250.

Mentlei R (1999) Dipeptidyl-peptidase IV (CD26)-role in the inactivation of regulatory peptides. Regul Pept 85:9-24.

Merchenthaler I, Lane M, Shughrue P (1999) Distribution of preproglucagon and glucagon-like peptide-1 receptor messenger RNAs in the rat central nervous system. J Comp Neurol 403:261-280. 
Nishino S, Ripley B, Overeem S, Lammers GJ, Mignot E (2000) Hypocretin (orexin) deficiency in human narcolepsy. Lancet 355:39-40.

Peyron C, Tighe DK, van den Pol AN, de Lecea L, Heller HC, Sutcliffe JG, Kilduff TS (1998) Neurons containing hypocretin (orexin) project to multiple neuronal systems. J Neurosci 18:9996-10008.

Peyron C, Faraco J, Rogers W, Ripley B, Overeem S, Charnay Y, Nevsimalova S, Aldrich M, Reynolds D, Albin R, Li R, Hungs M, Pedrazzoli M, Padigaru M, Kucherlapati M, Fan J, Maki R, Lammers GJ, Bouras C, Kucherlapati R, et al. (2000) A mutation in a case of early onset narcolepsy and a generalized absence of hypocretin peptides in human narcoleptic brains. Nat Med 6:991-997.

Powley TL (2000) Vagal circuitry mediating cephalic-phase responses to food. Appetite 34:184-188.

Qu D, Ludwig DS, Grammeltpft S, Piper M, Pelleymounter MA, Cullen MJ, Mathes WF, Przypek J, Kanarek R, Maratos-Flier E (1996) A role of melanin-concentrating hormone in the central regulation of feeding behavior. Nature 380:243-247.

Raufman J-P, Singh L, Singh G, Eng J (1992) Truncated glucagon-like peptide-1 interacts with exendin receptors on dispersed acini from guinea pig pancreas. J Biol Chem 267:21432-21437.

Rinaman L (1999) Interoceptive stress activates glucagon-like peptide-1 neurons that project to the hypothalamus. Am J Physiol 277:R582-R590.

Rossi M, Beak SA, Choi SJ, Small CJ, Morgan DGA, Ghatei MA, Smith DM, Bloom SR (1999) Investigation of the feeding effects of melanin concentrating hormone on food intake-action independent of galanin and the melanocortin receptors. Brain Res 846:164-170.

Sah P (1996) $\mathrm{Ca}^{2+}$-activated $\mathrm{K}^{+}$currents in neurons: types, physiological roles and modulation. Trends Neurosci 19:150-154.

Saper CB (2002) Central autonomic nervous system: conscious visceral perception and autonomic pattern generation. Annu Rev Neurosci 25:433-469.

Saper CB, Chou TC, Elmquist JK (2002) The need to feed: homeostatic and hedonic control of eating. Neuron 36:199-211.

Scrocchi LA, Drucker DJ (1998) Effects of aging and high fat diet on body weight and glucose tolerance in glucagon-like peptide-1 receptor $^{-1-}$ mice. Endocrinology 139:3127-3132.

Scrocchi LA, Brown TJ, MacLusky N, Brubaker PL, Auerbach AB, Joyner AL, Druker DJ (1996) Glucose intolerance but normal satiety in mice with a null mutation in the glucagon-like peptide-1 receptor gene. Nat Med 2:1254-1258.

Seeley RJ, Blake K, Rushing PA, Benoit SC, Eng J, Wood SC, D’Alessio D (2000) The role of CNS GLP-1-(7-36) amine receptors in the mediating the visceral illness effects of lithium chloride. J Neurosci 20:1616-1621.

Shapiro MS, Hille B (1993) Substance P and somatostatin inhibit calcium channels in rat sympathetic neurons via different $G$ protein pathways. Neuron 10:11-20.

Shen KZ, North RA (1992) Muscarine increases cation conductance and decreases potassium conductance in rat locus coeruleus neurons. J Physiol (Lond) 455:471-485.

Shimada M, Tritos NA, Lowell BB, Flier LS, Maratos-Flier E (1998) Mice lacking melanin-concentrating hormone are hypophagic and lean. Nature 396:670-674.

Smith BN, Davis SF, van den Pol AN, Xu W (2002) Selective enhancement of excitatory synaptic activity in the rat nucleus tractus solitarius by hypocretin 2. Neuroscience 115:707-714.

Sodickson DL, Bean BP (1996) $\mathrm{GABA}_{\mathrm{B}}$ receptor-activated inwardly rectifying potassium current in dissociated hippocampal CA3 neurons. J Neurosci 16:6374-6385.

Song Y, Huang L-Y (1990) Modulation of glycine receptor chloride channels by cAMP-dependent protein kinase in spinal trigeminal neurons. Nature 348:242-245.

Stocker M, Krause M, Pedarzani P (1999) An apamin-sensitive $\mathrm{Ca}^{2+}$ activated $\mathrm{K}^{+}$current in hippocampal pyramidal neurons. Proc Natl Acad Sci USA 96:4662-4667.

Tang-Christensen M, Larsen PJ, Goke R, Fink-Jensen A, Jessop DS, Moller M, Sheikh SP (1996) Central administration of GLP-1 (7-36) amide inhibits food and water intake in rats. Am J Physiol 271:R848-R856.

Thannickal R, Moore RY, Nienhuis R, Ramanathan L, Gulyani S, Aldrich M, Cornford M, Siegel JM (2000) Reduced number of hypocretin neurons in human narcolepsy. Neuron 27:469-474.

Thorens B (1992) Expression cloning of the pancreatic beta cell receptor for the gluco-incretin hormone glucagon-like peptide-1. Proc Natl Acad Sci USA 89:8641-8645.

Thorens B, Porret A, Byhler L, Deng S-P, Morel P, Widmann C (1993) Cloning and functional expression of the human islet GLP-1 receptor: demonstration that exendin-4 is an agonist and exendin-(9-39) an antagonist of the receptor. Diabetes 42:1678-1682.

Turton MD, O'Shea DO, Gunn I, Beak SA, Edwards DMB, Meeran K, Choi SJ, Taylor GM, Heath MM, Lambert PD, Wilding JPH, Smith DM, Ghatei MA, Herbert J, Bloom SR (1996) A role for glucagon-like peptide-1 in the central regulation of feeding. Nature 379:69-72.

van den Pol AN, Acuna-Goycolea C, Clark KR, Ghosh PK (2004) Physiological properties of hypothalamic MCH neurons identified with selective expression of reporter gene after recombinant virus infection. Neuron 42:635-652.

Vrang N, Phifer CB, Corken MM, Berthoud H-R (2003) Gastric distension induces c-fos in medullary GLP-1/2-containing neurons. Am J Physiol 285:R470-R478.

Yamamoto H, Lee CE, Marcus JN, Williams TD, Overton JM, Lopez ME, Hollenberg AN, Baggio L, Drucker DJ, Elmquist JK (2002) Central administration of glucagon-like peptide-1 agonist increases blood pressure and heart rate, activates autonomic regulatory neurons. J Clin Invest 110:43-52.

Yamamoto H, Kishi T, Lee CE, Choi BJ, Fang H, Hollenberg AN, Drucker DJ, Elmquist JK (2003) Glucagon-like peptide-1-responsive catecholamine neurons in the area postrema link peripheral glucagon-like peptide- 1 with central autonomic control sites. J Neurosci 23:2939-2946.

Yamanaka A, Beuckmann CT, Willie JT, Hara J, Tsujino N, Mieda M, Tominaga M, Yagami K, Sugiyama F, Goto K, Yanagisawa M, Sakurai T (2003) Hypothalamic orexin regulate arousal according to energy balance in mice. Neuron 38:701-713.

Yang B, Goulet M, Boismenu R, Ferguson AV (2004) Secretin depolarizes nucleus tractus solitarius neurons through activation of a nonselective cationic conductance. Am J Physiol 286:R927-R934.

Zhu Y, Yakel JL (1997) Modulation of $\mathrm{Ca}^{2+}$ currents by various $\mathrm{G}$ proteincoupled receptors in sympathetic neurons of male rat pelvic ganglia. J Neurophysiol 78:780-789. 